\title{
Deteksi Dini Pencegahan CA Servik dengan Pemeriksaan IVA Pap Smear di Rumah Cantik Almira Beauty Desa Tunggalpager Kec. Pungging Kab. Mojokerto Bekerja Sama dengan PKBI Kabupaten Mojokerto
}

\author{
Siti Fithrotul Umami ${ }^{1}$, Risna Zubaidah ${ }^{2}$, Titiek Idayanti ${ }^{3 *}$, Widya Anggraeni ${ }^{4}$ \\ ${ }^{1,2}$ AKBID Ar Rahma Indonesia \\ 3,4 STIKes Dian Husada \\ *Correspondent Author: ti2k.nurul@gmail.com
}

\begin{abstract}
ABSTRAK
Kanker serviks merupakan keganasan yang berasal dari serviks dan merupakan salah satu penyebab kematian pada wanita. Penyebab dari kanker serviks adalah infeksi Human Vapiloma Virus (HPV). HPV ditularkan melalui hubungan seksual dan ditemukan pada 95\% kasus kanker serviks. Data dari WHO (World Health Organization), kanker merupakan penyebab kematian nomor 2 di dunia. Kurangnya pengetahuan wanita usia subur tentang kanker serviks dapat berdampak pada tidak adanya perilaku untuk melakukan pemeriksaan dini dengan tindakan IVA. Dampak kanker serviks jika tidak segera dilakukan pemeriksaan pada organ reproduksi serviks beresiko keadaan kesehatannya telah menjadikritis atau penyakit sudah mencapai pada tahap stadium lanjut sehingga dapat berunjung pada kematian.

Kegiatan pengabdian kepada masyarakat ini dilakukan dengan tujuan membantu semua wanita usia subur yang ada di Desa Tunggalpager Kecamatan Pungging Kabupaten Mojokerto untuk dapat menditeksi secara dini adanya kelainan atau kondisi yang menunjukkan adanya tanda - tanda kearah kanker servik dengan melakukan pemeriksaan IVA dan Pap Smear. Kegiatan ini bertempat di RumahCantik Almira Beauty, yang di ikuti sejumlah 38 peserta. Sebelum pasien dilakukan pemeriksaan IVA \& Pap Smear, pasien dikumpulkan untuk diberikan edukasi tentang pengertian CA Servik, factor penyebabnya dan bagaimana cara mencegahnya. Setelah itu, setelah itu peserta di bagi 2 kelompok, masing - masing kelompok terdiri dari 14 oarang. Dari 14 peserta yang dilakukan pemeriksaan IVA didapatkan hasil 3 peserta terdapat kelainan servik yang dicurigai kea rah CA Servik. Sedangkan 14 peserta yang dilakukan pemeriksaan Pap Smear didapatkan hasil 6 pasien mengalami vaginitis.

Keberhasilan dari kegiatan ini diharapkan dengan mengetahui secara dini hasil pemeriksaan IVA Pap Smear, dan telah mendapatkan edukasi tentang CA Servik, diharapkan ibu - ibu aau peserta yang ikut dapat menjaga kesehatan reprodukasinya dan menerapakan pola hidup bersih dan sehat agar dapat meminimalkan dan mencegah terjadinya CA Servik. Setalah memahami pentingnya diteksi dini CA Servik dengan melakukan pemeriksaan IVA Pap Smear ini, diharapkan pula semua wanita usia subur tidak perlu takut untuk melakukan pemeriksaan IVA Pap Smear dan dapat melakukannya secara rutin setiap 1 tahun sekali.
\end{abstract}

Kata Kunci: Deteksi Dini Pencegahan CA Servik, Pemeriksaan IVA, Pap Smear

Received: July 8, 2021

Revised: August 10, 2021

Accepted: September 1, 2021

\section{(i) (9)}

This is an open-acces article distributed under the terms of the Creative Commons Attribution-ShareAlike 4.0 International License. 


\section{Journal of Community Engagement in Health}

http://jceh.org

https://doi.org/10.30994/jceh.v4i2.255

ISSN: 2620-3758 (print); 2620-3766 (online)

Vol. 4 No 2. Sep 2021. Page. 378-382

\section{PENDAHULUAN}

Kanker serviks merupakan keganasan yang berasal dari serviks dan merupakan salah satu penyebab kematian pada wanita. Penyebab dari kanker serviks adalah infeksi Human Vapiloma Virus (HPV). HPV ditularkan melalui hubungan seksual dan ditemukan pada 95\% kasus kanker serviks.

Data dari WHO (World Health Organization), kanker merupakan penyebab kematian nomor 2 di dunia. Pada tahun 2012 kematian akibat kanker serviks diperkirakan lebih dari 270.000 setiap tahunnya, lebih dari $85 \%$ terjadi di negara berkembang dan jumlah wanita penderita baru kanker serviks berkisar 90-100 kasus per 100.000 penduduk dan setiap tahun terjadi 40 ribu kasus kanker serviks. Kanker serviks merupakan penyakit kanker dengan prevalensi tertinggi di Indonesia yaitu sebesar $0,8 \%$.

Metode standar untuk deteksi dini kanker pada wanita adalah sitologi (papsmear) untuk kanker serviks dan mamografi untuk kanker payudara. Namun karena biaya pap smear dan mamografi senderung mahal dan butuh logistic, belum banyak fasilitas kesehatan khususnya di negara berkembang yang menyediakan layanan tersebut karena kendala infrastruktur. ${ }^{7}$

Program pemerintah mengenai deteksi dini kanker serviks sudah tercantum didalam Keputusan Menteri Kesehatan Republik Indonesia Nomor 796/MENKES/SK/VII/2010 tentang pedoman teknis pengendalian kanker payudara dan kanker serviks. Program deteksi dini kanker serviks yang dimaksud dalam peraturan ini yaitu pemeriksaan Inspeksi Visual Asam Asetat (IVA). Pemerintah menargetkan, pada tahun 2014 pencegahan dan penanggulangan kanker serviks dapat menjangkau hampir seluruh provinsi. Pada tahun 2014 25\% kabupaten/kota dapat melakukan deteksi dini terhadap kanker serviks dengan sasaran $80 \%$ wanita usia subur (WUS) berumur 15-49 tahun telah melakukan deteksi dini kanker serviks.

Kurangnya pengetahuan wanita usia subur tentang kanker serviks dapat berdampak pada tidak adanya perilaku untuk melakukan pemeriksaan dini dengan tindakan IVA. Dampak kanker serviks jika tidak segera dilakukan pemeriksaan pada organ reproduksi serviks beresiko keadaan kesehatannya telah menjadi kritis atau penyakit sudah mencapai pada tahap stadium lanjut sehingga dapat berunjung pada kematian. Sebagian besar pada penderita kanker serviks datang berobat sudah pada stadium lanjut. Hal ini dikarenakan kanker serviks tidak menunjukan gejala yang spesifik pada stadium dini atau bahkan pada tahap prakanker. Maka hal tersebut tidak heran kalau kanker serviks ini merupakan pembunuh wanita peringkat kedua setelah kanker payudara. Memang wanita sendiri tidak menyadari bahwa tubuhnya sedang "dikudeta" oleh sel-sel dalam tubuhnya sendiri.

Promosi kesehatan merupakan salah satu pencegahan primer yang dapat dilakukan guna mencegah kanker serviks. Pencegahan primer mengutamakan penguat fleksibilitas dalam melakukan pencegahan dengan cara mencegah dan mengurangi faktor risiko. Banyak metode yang dapat dilakukan untuk memberikan pendidikan kesehatan pada WUS, misalnya melalui penyuluhan, media elektronik dan media cetak.

Oleh karena itu penting dalam memberikan edukasi atau penyuluhan tentang kanker servik pada wanita usia subur, agar mereka mengetahui pentingnya melakukan diteksi dini kanker servik dengan cara melakukan pemeriksaan IVA atau Pap Smear. Kegiatan pengabdian kepada masyarakat ini dilakukan dengan tujuan membantu wanita usia subur untuk menditeksi dini adanya kelainan yang mengarah dan menunjukkan pada tanda - tanda adanya kanker sevik, serta untuk memberikan pengetahuan dan wawasan kepa peserta tentang kanker servik. 


\section{Journal of Community Engagement in Health}

http://jceh.org

https://doi.org/10.30994/jceh.v4i2.255

ISSN: 2620-3758 (print); 2620-3766 (online)

Vol. 4 No 2. Sep 2021. Page. 378-382

\section{METODE}

\section{Survei Lapanga}

Survei lapangan bertujuan untuk mengamati situasi dan keadaan Desa Taunggalpager Kec. pungging yang direncanakan sebagai objek sasaran.

2. Menentukan Sasaran

Sasaran program kegiatan PkM ini adalah semua warga wanita usia subur Desa Tunggalpager yang bersedia datang dan bersedia dilakukan pemeriksaan IVA Pap Smear.

3. Koordinasi

Berkoordinasi dengan pihak PKBI Kabupaten Mojokerto untuk pengajuan pengadaan alat dan bahan habis pakai, serta kebutuhan untuk persediaan alat pengambilan sampel pemeriksaan IVA Pap Smear, berkoordinasi dengan Bapak Kepala Desa dan pemilik Rumah Cantik Almira Beauty, yaitu untuk menentukan kesepakatan mufakat antara pelaksanaan kegiatan dengan masyarakat.

4. Sosialisasi Program

Sosialisasi kegiatan bertujuan untuk memberikan informasi mengenai rencana serangkaian pelaksanaan kegiatan yang disampaikan kepada Kepala Desa dan pemilik Rumah Cantik Almira Beauty, perangkat desa dan ketua RT setempat.

5. Pelaksanaan Kegiatan

Kegiatan PkM ini dilaksanakan pada Hari Minggu agar sasaran peserta banyak yang hadir. Kegiatan ini bertempat di Rumah Cantik Almira Beauty Desa Tunggalpager Kec. Pungging. Sebelum kegiatan ini berlangsung, di awal acarpeserta yang akan mengikuti pemeriksaan IVA Pap Smear dikumpulkan terlebih dahulu kemudian di berikan edukasi tentang kanker servik, factor penyebab terjadinya kanker servik, serta cara mencegahnya. Setelah peserta mendapatkan edukasi, satu persatu peserta dilakukan anamnesa untuk skrining riwayat kesehatan, kemudian peserta dilakukan pemeriksaan timabang berat badan, pemeriksaan tekanan darah, suhu, nadi dan pernafasan. Kemudian setiap pernafasan. Dan setelahnya peserta secara bergantian masuk keruang pemeriksaan untuk dilakukan pemeriksaan IVA Pap Smear. 14 pasien dilakukan pemeriksaan IVA, dan 14 pasien dilakukan pemeriksaan Pap Smear. Untuk hasil pemeriksaan IVA bisa langsung diketahui, sehingga petugas PkM lansung memberitahu hasil pemeriksaannya kepada paserta. Sedangkan pasien yang dilakukan pemeriksaan Pap Smear, hasil pemeriksaan akan dikirim ke alamat rumah peserta masing-masing. Hasil pemeriksaan akan diberikan 1 bulan setelah kegiatan selesai.

\section{HASIL}

Sebelum memulai pelaksanaan kegiatan penyuluhan dan sosialisasi ini, tim melakukan persiapan penyusunan proposal, kemudian menyusun materi, dan berkoordinasi dengan Kepala Desa dan Perangkat Desa serta pemilik rumah cantik Almira Beauty untuk menyesuaikan jadwal kegiatan. Tiap warga disemua RT kami berikan undangan.

Kegiatan ini secara garis besar menunjukkan respon yang positif, karena dari semua warga yang di undang, 80\% warga dapat hadir dalam kegiatan pemeriksaan IVA Pap Smear untuk diteksi dini pencegahan CA Servik.

\section{PEMBAHASAN}

Kanker serviks merupakan keganasan yang berasal dari serviks dan merupakan salah satu penyebab kematian pada wanita. Penyebab dari kanker serviks adalah infeksi Human Vapiloma Virus (HPV). HPV ditularkan melalui hubungan seksual dan ditemukan pada 95\% kasus kanker serviks. Data dari WHO (World Health Organization), kanker merupakan penyebab kematian nomor 2 di dunia. Kurangnya pengetahuan wanita usia subur tentang kanker serviks dapat berdampak pada tidak adanya perilaku untuk melakukan pemeriksaan dini dengan tindakan IVA. Dampak kanker serviks jika tidak segera dilakukan pemeriksaan pada organ reproduksi serviks beresiko keadaan kesehatannya telah menjadi kritis atau penyakit sudah mencapai pada tahap stadium lanjut sehingga dapat berunjung pada kematian. Namun sayangnya banyak wanita usia subur yang masih belum mengetahui apa yang harus dilakukan untuk mencegah dn menditeksi secara dini adanya kanker servik. Masih banyak wanita yang 


\section{Journal of Community Engagement in Health}

http://jceh.org

https://doi.org/10.30994/jceh.v4i2.255

ISSN: 2620-3758 (print); 2620-3766 (online)

Vol. 4 No 2. Sep 2021. Page. 378-382

belum sadar akan pentingnya melakukan diteksi dini kanker servik dengan cara melakukan pemeriksaan IVA atau Pap Smear.

Masih rendahnya pengetahuan dan kesadaran para wanita usia subur, mendorong kita untuk melakukan kegiatan pengabdian kepada masyarakat ini dengan tema diteksi dini CA Servik dengan melakukan pemeriksaan IVA Pap Smear. Kegiatan PkM ini dilakukan di Rumah Cantik Almira Beauty Desa Tunggalpager Kecamatan Pungging. Peserta yang hadir dan bersedia dilakukan pemeriksaan sebanyak 38. Dari jumlah peserta tersebut langsung di bagi 2, sehingga 14 pesertadilakukan pemeriksaan IVA dan 14 peserta yang lain dilakukan pemeriksaan Pap Smear. Sebelum pemeriksaan dimulai, peserta berkumpul dan mendapatkan edukasi tentang CA Servik. Setelah mendapatkan edukasi, pasien di anamnesa tentang riwayat kesehatan dan penyakit untuk skrining awal. Setelah itu peserta secara bergantian dilakukan pemeriksaan tand - tand vitl meliputi tekanan darah, suhu, nadi, dan pernafasan serta timbang berat badan. Kemudian peserta secara bergantian masuk keruang periksa untuk dilakukan pemeriksaan IVA dan Pap Smear. Hasil pemeriksaan menunjukkan dari 14 peserta yang dilakukan pemeriksaan IVA didapatkan hasil 3 peserta terdapat kelainan servik yang dicurigai kea rah kanker servik. Sedangkan 14 peserta yang dilakukan pemeriksaan Pap Smear didapatkan hasil 6 peserta mengalami vaginitis.

\section{KESIMPULAN}

Keberhasilan dari kegiatan ini diharapkan semua wanita subur sadar akan pentingnya melakukan diteksi dini kanker servik dengan melakukan pemeriksaan IVA atau Pap Smear rutin setiap 1 tahun sekali. Diharapkan setelah mendapatkan edukasi tentang kanker servik, para wanita usia subur dapat menerapkan pola hidup bersih dan sehat agar terhindar dari berbagai macam penyakit termasuk kanker servik. Penggunaan alat kontrasepsi hormonal dalam jangka panjang juga dapat menyebabkan kanker servik, sehingga diharapkan wanita usia subur mengganti jenis KB nya setiap 5 tahun sekali.

\section{UCAPAN TERIMA KASIH}

Ucapan terima kasih kami sampaikan kepada seluruh pihak yang telah membantu dan ikut berperan serta dalam pelaksanaan kegiatan PkM ini baik secara langsung maupun tidak langsung. Terima kasih kami sampaikan kepada pkbi Kabupaten Mojokerto yang telah menyuplai dan menyediakan alat habis pakai dan bahan - bahan untuk melakukan pemeriksaan IVA Pap Smear, terima kasih kepada Bapak Kepala Desa Tunggalpager beserta seluruh perangkat desa dan pemilik rumah cantik Almira beauty yang telah mengijinkan danmemebrikan kesempatan kepada kami untuk melaksanakan program PkM ini. Terima kasih kepada seluruh warga yang antusias dan bersedia menghadiri acara kegiatan PkM diteksi dini CA Servik dengan melakukan pemeriksaan IVA Pap Smear.

\section{REFERENSI}

Komite Penanggulangan Kanker Nasional. Panduan Penatalaksanaan Kanker Serviks. Kemenkes RI; $1-7$

Global Cancer Statistics . (2018). GLOBOCAN 2018 : Estimates of Incidence and Mortality Worldwide for 36 Cancers in 185 Countries.

Kemenkes.2015.Infodatin Kanker.Jakarta: Kementerian Kesehatan RI. 2-5

Dinkes DIY.2018.Profil Kesehatan Provinsi Daerah Istimewa Yogyakarta Tahun 2018.Yogyakarta: Dinas Kesehatan DIY.

Kemenkes RI.2017.Profil Kesehatan Indonesia 2017. Jakarta: Kementerian Kesehatan RI.

Kemenkes RI.2015.Buletin Jendela Data dan Informasi Kesehatan. Jakarta: Kementerian Kesehatan RI. 


\section{Journal of Community Engagement in Health}

http://jceh.org

https://doi.org/10.30994/jceh.v4i2.255

ISSN: 2620-3758 (print); 2620-3766 (online)

Vol. 4 No 2. Sep 2021. Page. 378-382

Kemenkes RI.2018.Profil Kesehatan Indonesia 2018. Jakarta: Kementerian Kesehatan RI.

Fauza,M. dkk. 2019. Faktor yang Berhubungan dengan Deteksi Dini Kanker Serviks Metode IVA di Puskesmas Kota Padang. Jurnal Promosi Kesehatan Indonesia Vol. 14 / No. 1 / Januari 2019.

Febriani, CA. 2016. Faktor-Faktor Yang Berhubungan Dengan Deteksi Dini Kanker Leher Rahim Di

Kecamatan Gisting Kabupaten Tanggamus Lampung. Jurnal Kesehatan, Volume VII, Nomor 2, Agustus 2016, hlm 228-237.

Notoatmodjo, S.2010. Ilmu Perilaku Kesehatan.Jakarta:Rineka Cipta.

Notoatmodjo, S. 2012. Promosi Kesehatan dan Perilaku Kesehatan. Jakarta: Rineka Cipta.

Fertman CI and Allensworth, DD. Health Promotion Programs from Theory to Practice. United States of America: Jossey-Bass; 2010.

Rasjidi I. 2009.Deteksi Dini \& Pencegahan Kanker pada Wanita.Jakarta: Sagung Seto.

Kemenkes RI.2015.Panduan Program Nasional Gerakan Pencegahan dan Deteksi Dini Kanker Leher Rahim dan Kanker Payudara. Jakarta: Kementerian Kesehatan RI.

Wulandari,S., Sri Wahyuningsih, Ferdiana Yunita.2016.Faktor-faktor yang Berhubungan dengan Perilaku Pemeriksaan Inspeksi Visual Asam Asetat (IVA) pada Wanita Usia Subur (WUS) di Puskesmas Sukmajaya Tahun 2016.JK Unila,Volume 2,Nomor 2, Juli 2018.

Wantini NA, Novi I.2018.Deteksi Dini Kanker Serviks dengan Inspeksi Visual Asam Asetat (IVA).Jurnal Ners dan Kebidanan, Volume 6, Nomor 1, April 2019, hlm. 027-034.

Parapat FT et al. Faktor-Faktor yang Berhubungan dengan Perilaku Deteksi Dini Kanker Leher Rahim Metode Inspeksi Visual Asam Asetat di Puskesmas Candiroto Kabupaten Temanggung. Jurnal Kesehatan Masyarakat. 2016; 4 (4): 363-370.

Azwar S.2012.Sikap Manusia: Teori dan Pengukurannya.Yogyakarta: Liberty 